\title{
Professionalising Local Government Leadership: A Foundational Imperative
}

\author{
Commonwealth Journal of Local Governance \\ Issue 8/9: May-November 2011 \\ http://epress.lib.uts.edu.au/ojs/index.php/cjlg
}

\section{Olubunmi Ajayi}

Secretary-General

African Commission for Local Government Improvement

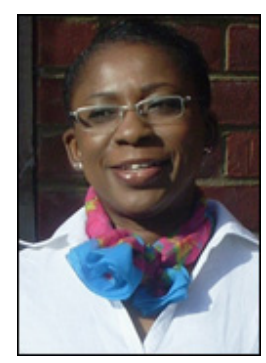

\section{Introduction}

'If you have built a castle in the air your work need not be lost - that is where they should be. Now put the foundations under them.' (Henry Thoreau)

First, the good news. Africa's economic pulse has quickened, infusing the continent with a new commercial vibrancy. Real GDP rose by 4.9 percent a year from 2000 through 2008, more than twice its pace in the 1980s and 1990s. Telecommunications, banking, and retailing are flourishing. Construction is booming. Private-investment inflows are surging. Africa's collective GDP, at $\$ 1.6$ trillion in 2008 , is now roughly equal to Brazil's or Russia's, and according to the McKinsey Quarterly, 'What's driving Africa's growth' (2010), the continent is among the world's most rapidly growing economic regions. This acceleration is a sign of hard-earned progress and future promise.

There is also good news about public management. According to the African Development Bank (2011), many African countries are making significant progress in improving public financial management. In recent years, public expenditure management in several countries has improved, regulatory and supervisory bodies have been strengthened, and tax systems have been reformed towards internationally recognized standards of good fiscal practice. A 
World Bank and Brookings survey of 31 African countries, found that at least 25 had adopted reforms involving payroll, procurement, internal audit and external audit (Andrews 2010).

However, development is of course about more than just improving people's economic and financial situation and many of Africa's 50-plus economies still face hugely challenging issues of poverty, social inequity, social justice, security and corruption, issues that cannot simply be addressed by economic growth alone. So there is a need for further progress. Many of the reforms have been applied at the central or federal level and have not filtered sufficiently or at all to local government level. There is limited institutional and human capacity. Whilst, a lot of attention has been given to the legal frameworks and budgeting methodologies, there has not been enough focus on the development of professional skills in the public sector, and historically it has been hard to attract people to work in the African public sector because of the poor pay levels and archaic systems of government, particularly in local government.

The Local Government Service in Africa today is still fundamentally the product of the nineteenth century colonial philosophy although the problems it faces are those of the twenty first century. In spite of some progress in some areas, it remains inadequate for the most efficient discharge of the present and prospective responsibilities of government. To the credit of some African countries, there has been an increased adoption of reforms, but in general there is still a lack of strong, stable local governments. The progress made by some governments in the past ten years is noteworthy. However, the challenges remain colossal. Evidence of poor service; citizen discontent and dissatisfaction; incompetency; poor leadership; and adverse audit reports all point to the need for greater capacity to be able to fulfil the shared vision of an effective and innovative local government sector.

Across Africa, there is a need to come to grips with the reality of our situation however disheartening it may look and feel. Whilst we have legitimate and proud cause to celebrate our successes to date, our "castles" which are symbols of our success cannot be grounded without significant development and professionalization of the local government sector. Well thought-through and effective efforts have got to be made to ensure that political leaders, 
executives and administrators have the right mix of skills and expertise to enable their departments or agencies to deliver effective services. To this end, the goal must be to professionalise the business of government. Given the increasing investment in capacity building and the acute shortage of local government professionals, it is time to work together to build set standards across the local government sector; develop the leaders that can transform the sector; and develop professional practice in local government. With the right, robust and rigorous interventions and support, local government can truly become a vehicle for lasting development. And the aim of this paper is to stimulate and facilitate a collaborative inquiry into the need, motivations and benefits for a professionalised local government.

\section{Local Government and Professionalisation}

There is a general consensus about what local governments should be doing in Africa (as indeed, around the globe). We want local governments that can:

- provide effective municipal governance;

- provide community and democratic leadership;

- provide efficient services;

- empower communities and citizens;

- provide strategic leadership - setting vision,

- be effective regulators - licensing, environmental

- health, planning, trading standards, etc;

- collect and administer taxes effectively

- be a scrutineer - for the sector

- be shaper of the economic and physical development of communities.

But local government will not be up to these multiple tasks unless it develops the necessary human capital through the injection of professionalisation and professional practices.

Africa's urgent priority is to reduce poverty through strong and sustained economic growth and improved services that benefit the poor. But no country has succeeded with levels of human development as low as those found in the majority of African countries today. The development of human capital is one of the major challenges facing the region and is a 
critical factor in the fight to reduce poverty and reach the Millennium Development Goals. Human capital includes the attributes of a person that are productive in some economic context. It often refers to formal educational attainment, with the implication that education is an investment whose returns are in the form of wage, salary, or other compensation. These are normally measured and conceived of as private returns to the individual but can also be social returns. Professionalisation can be seen as a process of building upon this formal educational attainment with a view to skills enhancement and specialization.

In a recent interview Ritva Reinikka, World Bank Director for Human Development in Africa, highlighted the importance of human development in the run-up to 2015 when the Millennium Development Goals are due. She stated that:

It's certainly true that a lot of physical capital must be built quickly in Sub-Saharan Africa. By that I mean roads, electricity, water supply, internet connectivity, and so on. But the other side of the coin is that countries also need to build "human" capital. That is, a skilled and knowledgeable workforce that can contribute to the economy productively. So countries need to make sure that people are healthy, well-educated, and have the right skills for jobs, and that they are protected from poverty and hunger (World Bank 2011).

There is no doubt that efforts at public sector reform are succeeding in some areas. However, without an urgent investment in professionalisation, noble national and state aspirations and the influx of donor aid will only achieve minimal improvements.

\section{What We Do Not Mean By Professionalism}

Whilst there is general agreement that skills need to be improved in order to generate sustainable change and improvements in local government administration, a highly skilled service is not an end in itself. It is important to be clear about what we do not mean by professionalisation. According to Wilensky (1964), this label is loosely applied to increasing specialization and transferability of skill, the proliferation of objective standards of work, the

spread of tenure arrangements, licensing, or certification, and the growth of service occupations. Professionalism, by definition, involves belonging to a profession and is about behaving in a way that is consistent with certain professional standards. A profession is an occupation that requires extensive training and the study and mastery of specialized knowledge. It usually requires accreditation, certification, or licensing. It has a specific code of ethics, and it holds members accountable. (Carter and Wilson 2006). 
Professionalisation of Local Government cannot be used as a blanket term because the sector is made up of several professional streams. Professionalisation of local government is therefore about more than improving professional practice. It is also about institutional capacity and can only be achieved through cultural and behavioural change. So it is important to differentiate between the structural and behavioural attributes of professionalism. Professional associations have a vital role to play in ensuring standards in local government services but efforts to build institutional capacity must be targeted at bringing about change in behaviours and attitudes, both at the leadership and grassroots level. Professionalism means having an internal set of standards of performance and behaviour. Professionals aspire to high ideals: altruism; honour and integrity; respect; excellence and scholarship; caring, compassion, and communication; leadership; and responsibility and accountability. (Carter and Wilson 2006). Professionalisation is about espousing a particular philosophy of how we govern in local government - the aim is to professionalise the business of local government.

\section{Enabling Conditions for a Professional Local Government}

In spite of progress made to date, local government in Africa still remains inadequate in seven important respects. It is still too based on the philosophy of the amateur (or "generalist" or "all-rounder"). This is most evident among the senior ranks. Second, the present system of categories and grading in the local administration, (each for the most part with its own separate pay and career structure) seriously impedes its work. Third, members of specialist classes such as finance, planners, and engineers are frequently given neither the full responsibilities and opportunities nor the corresponding authority they ought to have. Fourth, there are too few staff is skilled managers or leaders. Fifth, there is not enough contact between local councils and the communities they are there to serve. Sixth, human resource management and career planning are inadequate. Finally, there is a problem of poor pay in comparison to other sectors.

There is a need to improve local government capability in all these areas so that local government staff have the right mix of skills and expertise to enable their departments (be it in policy delivery, operational service delivery and corporate service delivery (including 
services such as finance, ICT, communications and HR) to deliver effective services to citizens. There is a need for staff and leaders to have the right attitude and behaviours in order to serve their citizens and local communities effectively. It is about injecting dignity into local government administration by moving away from the concepts of "generalist" and "specialist", and to create a Local Government sector where all staff is specialists of one form or another and leadership is distributed. We know that systems with years of tradition and embedded bureaucracy behind them won't be easy to change. Before real progress can be achieved, we must cultivate the conditions under which change and this means tackling a range of issues.

\section{Elitism}

Historically across the world, the public sector is rife with elitism. In Africa, there is a tendency to view local government as inferior to other parts of the civil service. Policy work is the most revered and the one linked to promotion. What is needed is whole-systems professionalisation so that the key work streams of local government including policy, finance, human resources and general management, carry equal esteem and all three should provide opportunities for promotion. This should be reflected in the processes of attraction; recruitment; selection; retention and refreshment.

Staff should be encouraged early in their careers in local government to choose whether to pursue a career in a particular profession - such as a professional policy delivery specialist or a professional public finance management (PFM). Although all careers should include experience of at least two professions and preferably more, individuals should major in one of those. They should then be advised to plot career paths accordingly (for example, a professional policy adviser might gain operational delivery experience by working in a management or leadership role). For the upper echelon, standards can be raised so that there is a minimum requirement for entrants including the need to be skilled in organisations; management theory and practice; and the experience of managing complex organisations and; a commitment to continuous professional development. For the lower echelon, there should be a process whereby the everyday skills of civil servants is recognized through some kind of vocational qualifications that can be graduated into either academic or professional qualifications. In an effort to raise standards, the following core skills should be made mandatory for senior local government officials: 
- Analysis and use of evidence;

- Financial management;

- People management;

- Programme and project management;

- Strategic thinking; and

- Communications.

\section{Standards}

Raising professional standards is a core strand of public sector reforms. People need to know what standards are expected and what behaviours underpin them. All over Africa, governments should be seeking to rebuild citizens' trust and confidence in local government administration by raising standards of professionalism across the sector. One of the key ways of doing this is for local governments to build in house capacity though the achievement of higher level qualifications; meeting enhanced standards of continuing professional development; and adhering to common ethical standards.

\section{Pay}

The issue of poor pay is important because it contributes to two big problems in local government: attrition and corruption. Generally, local government is seen as a last resort for desperate people who are hoping to supplement their income by moonlighting and conducting business during office hours so that they can make ends meet. The public sector, and in particular, local government, continues to experience a drain of talent to the private sector (including foreign companies) and NGOs, even losing talent to the very aid agencies that are supposed to be helping governments build their capacity (Wuyts 1996). Although it can be difficult to close the pay gap between the public sector and the private sector, this is an issue that must be addressed, and urgently, for there to be a demonstrable improvement in the attraction, recruitment and retention of talent to local government.

\section{Corruption}

The issue of low pay is strongly linked to corruption and lack of individual and organizational discipline. Local government employees resort to all sorts of unethical practices in order to make ends meet. This is an endemic problem especially as some particular pockets of the administration are seen as "to die for money-making zones". 
Weaning employees off unethical practices and bribery will be impossible without pay reform fostering the principles and practices of individual and collective social responsibility and accountability.

\section{Career Progression and Meritocracy}

Although one of the essential pillars of public sector reform and professionalisation is meritocracy, it is not always easy to achieve in any country, and is particularly difficult in Africa. There is a historically based on aristocracy with a perceived right to privileged positions, including the upper echelon of civil service. In a world where who you know, where you went to college, and your surname does matter, the upper echelon has become a class of its own. Rules of fairness and equal opportunities can be used to create more favourable conditions for meritocracy in local government including:

- The injection of competition into recruitment and selection processes so that the best candidate gets the job;

- Basing recruitment on competencies and experience by adherence to strict and enforceable codes and processes of recruitment and selection;

- Recognition of non-academic qualifications (on-the-job learning) and past professional performance; and

- Matching past performance to the job requirements.

There should be further improvement to the recruitment and induction practices that provides recruits with support and a more open culture with is conducive to success. This requires significant management and leadership commitment.

\section{Legal and regulatory framework}

There must be robust legal and regulatory frameworks to ensure compliance with the professionalisation agenda.

\section{Training}

Training is vital to professionalism but it cannot simply a case of training for the sake of training. It is impossible to build capacity if we cannot identify the skills that are needed. Local governments should invest in a coherent strategy that helps to identify skills gap in 
administration and leadership. Training must have four overlapping but complementary objectives:

- To enhance technical capacity;

- To strengthen core professional skills;

- To facilitate change; and

- To change behaviours and attitudes.

The goal of professional training should be to improve employee performance and achievement. To be judged effective, therefore, training must result in ongoing benefits as measured by improvements in employee performance. However, there is a growing body of research that shows that much training does not lead to long-term changes in practice. Therefore, the focus for professional development must not be limited to external courses and workshops but needs to embrace the development of strong professional learning communities within local governments where professional learning is built into employees' every day working lives and responsibilities. In addition, training programmes must also be improved to build in some cross-boundary learning or work experience to boost organisational versatility and agility.

Beyond accrediting the skills of existing and future staff, local government must invest more in its employees by providing formal and informal training to develop their skills. Legal and human Resource frameworks must ensure that employees have access to appropriate training throughout their careers in local government. Such access clearly depends on a number of factors, from the suitability of training offered, to the adequacy of time and money available.

\section{Attitude}

Any attempt at establishing the elements that constitute appropriate professionalism is complex. This is because professionalism stretches along a continuum from the individual (beliefs, attitudes, behaviours and attributes) through the interpersonal domain (interactions with citizens and communities and fellow staff), to social responsibility and ultimately, political agendas. 
It requires a culture that fosters continual improvement and emphasises both personal and collective responsibility for improvement in local government. Because professionalism is not simply a technical matter of acquiring or updating skills, but covers a myriad of cognitive and attitudinal elements, it needs to address required changes in behaviours and attitudes that incorporates the determination of required level of individual and organizational competency in local government professionalism against world best sector standards is essential. Therefore, the professionalisation agenda should be a hybrid of extending the use of accredited qualifications; on-the-job training; and creating the right environment, structure and cultural climate for a professionalized local government. This diversity of approach is absolutely critical to getting it right.

\section{Leadership}

Professionalism must cut through all levels of local government. It is not uncommon to find the blind leading the dumb in local government. Neither is it uncommon to find unskilled, inexperienced and uneducated people at leadership levels. Local government needs qualified, well-trained, experienced and committed leaders who observe and honour the democratic processes and who are professional in their practice.

Leaders have a very important role to play in steering the organisations towards change and mobilising teams. For successful professionalisation of local government, there is a need for senior civil servants in local government to "be the change they wish to see". It is no use the leaders pointing the fingers at the shop-floor and saying, "they must change". Bad leadership practices at the upper echelons sets the tone for organisational behaviour and diminishes collective responsibility and accountability. It is not merely a case of demanding change from the grassroots; this is a case of leading by example. Efforts must also be made to reduce the rate of turnover of local government leaders in order to provide a better degree of stability and to preserve organisational memory. This is vital to the professionalisation process because of the need to transfer skills sideways and downwards as well as through team working. This requires a process of change from the bureaucratic and arms-length leadership to a new, engaging, responsive and professional style which also promotes responsibility and accountability in action. 


\section{Political Will}

Success in our efforts to professionalise local government depends on various factors: a common definition of professionalisation; identifying the most appropriate approach; promoting new policies that foster professional practice. But it also depends on the mobilization of political will. This is the engine of change and the most powerful tool in the transformation of local government; and it is needed to reach agreements on what needs to be done and to start taking immediate action.

To move forward with the professionalisation agenda, political leaders will have to take decisions that involve risks and political costs. There is no swapping of price tags. To obtain the collective will, they will need to work collaboratively to provide countries and decision makers with high quality analysis; objective and reliable economic evidence and serious predictions with clearly thought-through scenarios for improvement. They will also need to know what has worked or not to date and the lessons that have been learnt so that they can compare their country's performance and plan for change and improvements.

Any measures to strengthen the professionalisation of local government requires political will and a socially and politically responsible leadership (as the quote goes, "the fish rots from the head". This powerful combination of political will and leadership, if achieved, will overcome resistance, build grassroots advocacy for change and start to address the habits and behaviours of civil servants in local government.

\section{Measuring Professionalism}

Given that the definition of professionalism is complex, careful consideration has to be given to how we measure professionalism and what degree of it can be attributed to success in public sector reform and new public management efforts. Furthermore, there is the issue of what is being measured; what aspect of employees' performance is being predicted for improvement; and what numbers of measures are to be selected. This is recommended as an area for further study. 


\section{Conclusion}

Castles in the air need foundations. People throughout the region are beginning to realize that whilst dramatic words and phrases might provide a temporary reprieve, they cannot satisfy their aspirations for a better life. What is needed is a philosophy of critical reflection and practical action that induces change simultaneously at both state and local government levels. There is a need courageously to confront the continent's challenges at grass roots level which manifest themselves in the corrosion of local government and local services.

First and foremost, we need to come to grips with the reality of our situation, however disheartening it may look and feel, and take conscious and determined steps to address the challenges facing us in local government. This paper is a call for an honest undertaking to reshape our values; to re-build the lives in our communities; and restore some modicum of confidence in our citizens - those whom we govern, those who elect us. The challenges facing local government are enormous but we need to consciously and willingly embark on a journey of reform and we must do it in a new way. We must stop doing what I call 'constipation management' (by which I mean, if it does not work, try harder!).

The rationale for professionalisation is based on the conviction that a strong and vibrant local government is essential to the attainment of a society and region in which all citizens have access to basic services; equal opportunities; and have real opportunities to participate in and shape their local communities. And for this we need a highly skilled workforce with the right mindset and behaviours; and corresponding enabling culture and leadership.

The professionalisation of local government cannot take place in a vacuum and must be part of the whole-system change of public sector reform and new public management, where it is applied. Public sector reforms have got to be integrated and interactive to ensure success and to work together to create good governance. All across Africa, people want their locality to be one where they have a high quality of life and good life chances. They want a pleasant, safe, clean and green environment with low levels of crime, clean water, and no rubbish. They want a strong local economy with a wide range of opportunities for employment, fair access to services and equal opportunities for lifelong learning. They want to live in socially cohesive communities where the vulnerable are protected; do not lose their dignity; where all 
individuals are respected; and where people have a sense of pride and care about the place in which they live.

Globally, we continue to experience unrelenting change, and in terms of globalisation of the economy, new technologies and balance of power. Inherent in every change is the opportunity for improvement. The opportunities to create a $21^{\text {st }}$ century local government in Africa require professionalisation of its administration underpinned by good governance. Indeed, local governments everywhere need administrations that have well-trained, experienced, committed and well paid staff to achieve their goals of efficient and effective delivery of public service supported by dynamic and fruitful citizen engagement.

Regardless of the challenges and their capacity constraints, local governments are still better placed than anyone else to respond to the needs of their citizens simply because they are the closest to them. Evidence and experience demonstrate that the best way of building capacity in local government is to put resources at the disposal of local governments so that they can learn their jobs through doing their jobs. Development of human resources in both public and private sector organizations has become critical in an increasingly knowledge-based globalizing economy (Analoui, 2002). One cannot over-estimate the strategic importance of professionalisation in the public sector reform because of its implications for improved development, leadership and good governance. At the World Bank notes: 'Africa's future lies in its people. Indeed, Africa must solve its current human development crisis if it is to claim the $21^{\text {st }}$ century. Africa's future economic growth will depend less on its natural resources, which are being depleted and are subject to long-run price declines, ... and more on its labour skills and its ability to accelerate a demographic transition' (World Bank, 2000, p.103).

Africa's most precious resource is its human capital and, just as a diamond has to be polished, human capital must be developed and professionalised to unleash its potential and to make reform possible and sustainable. The challenge is real but it is not insurmountable. We have already begun to build castles of public sector reform, now we need to put the foundations under them. 


\section{References}

African Development Bank (2011). Economic \& Financial Governance Group $<$ http://www.afdb.org/en/topics-sectors/sectors/economic-financial-governance/>

Analoui, F. (2002). The Changing Patterns of Human Resource Management. Ashgate: Aldershot.

Andrews, M. (2010). How Far Have Public Financial Management Reforms Come in Africa? Faculty Research Working Paper Series, RWP10-018. Harvard Kennedy School:

Daddah, T O, (1998), Public Service in Africa: Professionalism: Public Service in Africa: New Challenges, http://unpan1.un.org/intradoc/groups/public/documents/un/unpan000388

Carter, L. and Wilson, M. (2006). Measuring Professionalism of Police Officers. The Police Chief, 73 (8): 42-44.

Leke, A., Lund, S., Roxburgh, C., and van Wamelen, A. (2010). What's driving Africa's growth. McKinsey Quarterly. June.

$<$ http://www.mckinseyquarterly.com/Whats_driving_Africas_growth_2601>

Wilensky H L. (1964). The professionalization of everyone? American Journal of Sociology. 70 (2):137-58.

World Bank (2000). Can Africa Claim the $21^{\text {st }}$ Century? World Bank: Washington D. C.

World Bank (2011). Why Should People Invest In Africa Now. World Bank: Washington D. C. $<$ http://web.worldbank.org/WBSITE/EXTERNAL/COUNTRIES/AFRICAEXT/0,,print:Y isCURL:Y contentMDK:22819434 menuPK:2246551 pagePK:2865106 piPK:2865128 theSitePK:258644,00.html>

Wuyts, M. (1996). Foreign Aid, Structural Adjustment, and Public Management: The Mozambican Experience. Development and Change. 27 (4): 717-49. 